\title{
Instructional Material Based on WhatsApp for Speaking Classroom in Private University: A Need Analysis
}

\author{
Areski Wahid ${ }^{1, *}$, Doni Sudibyo ${ }^{2}$ and Hardianti ${ }^{3}$ \\ ${ }^{1}$ Universitas Negeri Makassar, Indonesia and ${ }^{2}$ Universitas Pendidikan Muhammadiyah Sorong, Indonesia and \\ ${ }^{3}$ Universitas Muhammadiyah Luwuk Banggai,Indonesia \\ *areskiwahidddd@gmail.com
}

\begin{abstract}
In teaching and learning, instructional material is important in need analysis for the students Need analysis is the way to know the necessities, lacks, and wants in the environment. The objective of the research is to know the characteristic of need analysis in instructional material based on Instagram for speaking classroom in Private University. The sample of this study is the students in Universitas Muhammadiyah Luwuk Banggai, there are 20 students in speaking classroom. The data obtained from the questionnaire and interview which based on google form and conversation between the students and lecturer. The result of this study shows that the characteristics of need analysis of students in speaking classroom at Universitas Muhammadiyah Luwuk Banggai which consists of materials covers of speaking through WhatsApp, some quizzes are implemented, the material touches of technology, the material is provided by grammar, vocabularies, spelling, pronunciation, answer key, review, and conclusion. Based on the findings, it concludes that need analysis is important for instructional material by using WhatsApp in speaking classroom to know the necessities, lacks, and wants. Hopefully, this study can be a contribution to learning and teaching material in speaking classroom for the technology acceptance for the students and lecturer.
\end{abstract}

Key words: Characteristic, instructional material, need analysis, speaking, WhatsApp.

\section{Introduction}

In teaching and learning, instructional material is important in need analysis for the students Need analysis is the way to know the necessities, lacks, and wants in the environment. The objective of the research is to know the characteristic of need analysis in instructional material based on Instagram for speaking classroom in Private University. These things are urgent to discuss about instructional material. Instructional material is one of the important in learning and teaching process, it is useful in learning material. Every course in the school curriculum requires the use of instructional materials. The students allow to engage with words, symbols, and ideas in ways that improve in reading, listening, problem-solving, viewing, thinking, speaking, and writing skills, and also the capacity for using media and technology. In case, instructional material can help students in engaging the material and the needs of the student's ability to get the goals of learning and teaching material 
Instructional material is a tool helps students to support for learning and teaching process. A tool means any resources from the teachers to have attention for the students in encouraging them in learning material. Instructional material is a resource helps the source and receiver (teacher and student) to send and share a message by using the material[1]. Instructional material is essential tool in learning every subject for the curriculum which the students can interact with words, symbols and ideas to develop their ability in every skill in English[2]. Therefore, having material is meaningful for the teacher to communicate to the students about learning and teaching process.

Particularly, speaking is also part of English for the students' needs to speak the idea and information including social media. Speaking is the way to express the idea or message by orally or written forms. Speaking involve cognitive and psychology process to challenge the learner[3]. However, the students have less of opportunity to speak. As a teacher looks for the way for the students practice their speaking skill and media social is the answer for students' needs in learning and teaching process. In addition, speaking is the stressful way based on the age who are speaking. To decrease the stress or anxiety in speaking skill are needed methods to handle it because anxiety can appear from the students' feeling and insecure to speak with people. One of the methods is involving social media as a tool whenever and wherever the students' wants and needs[4].

The problems appear for the students and lecturers in Universitas Muhammadiyah Luwuk Banggai 2021/2022 for speaking class in English Department so research purposed the idea to know instructional material based on WhatsApp for speaking classroom in private university: a need analysis in Universitas Muhammadiyah Luwuk Banggai

Moreover, WhatsApp is the urgency things to use for the students in learning and teaching process. WhatsApp are the necessities for the students in 4.0 industrial revolution, most of the students' needs are provided in WhatsApp media to support their daily activities. Then, the research will conduct research and development then ADDIE Branch is as development of instructional material for this research. Based on the explanation, the researcher conducted for need analysis for instructional material for speaking skill in Universitas Muhammadiyah Luwuk Banggai. Based on the explanation, the objectives of this research will find out the characteristics of instructional material based on WhatsApp for speaking classroom in private university: a need analysis in Universitas Muhammadiyah Luwuk Banggai.

\section{Instructional Material}

As a tool for teaching and learning process, instructional material also has the usefulness for getting educational objectives. Besides, instructional can be as a goal for material to encourage the student's environment and motivation[5]. Then, Instructional material has an objective to combine between the learning and learner's mind. By having those items, the students can improve the quality of learning experiences to correlate the students' reality life. Therefore, instructional material can be utilized in teaching and learning process[6].

Beside the usefulness of instructional material, it also takes important part for the students' outcomes in learning and teaching process. Instructional material relates to the outcome learning-teaching process which focuses on the objectives and goals for the material[7]. Therefore, this instructional material creates a model to evaluate the process regarding on the objectives and goals improving learning and teaching for the material. Likewise, instructional material is as the abilities, intellectuals and attainments of teaching and learning material for the learners to get the achievement but it cannot be over emphasize to have a goal because giving the pressure for the students effects the students' accepting of the material[8]. Thus, instructional material controls the goal and outcomes for the students to get a good achievement in learning and teaching process which is better to implement for the students.

Getting the students' achievements for an objective learning is the advantage of instructional material and there are many advantages that explained by some authors. Instructional material designs with appropriate material in teaching process, it depends on the subject area that focus in[9]. By doing these things, instructional material has appropriate ways to teach the students. Having appropriate teaching for learning material regards to the evaluation of appropriateness and characteristic of instructional material. Shortly, it can identify the students' needs. In addition, students' need for learning is the advantage of instructional itself. Students needs can suit with the method and technique for the students. Furthermore, instructional material can be as target language in the future for the students' work area and cover the students' weakness where it must be added or not in learning and teaching process. The students' needs have been implemented in learning and teaching to find out the objectives of material[10]

The students' needs are important to create instructional material for the students, instructional material deals with the social media to design the students' ways. In the 4.0 industrial revolution, social media takes part to share the information for the students' in learning and teaching process. Based on Appel et al. (2020) explains that social media is a form of application to send and receive the information digital for the major platform and feature such as Facebook, Instagram and Twitter[11]. Besides, social media is also as a place to share and make the existence of the environment life for the people in digital and real life. Similarly, [12] Social media is a digital platform where the people across the world can interact each other's. In addition, social media can change thoughts and ideas through publishing information, pictures, video, etc. By this explanation, people can see and give the perspective for an 
information. Therefore, social media is a source of information to share and receive by using platform as application to use for online form.

This researcher will focus on some social media that the students usually use in daily life for instance Instagram, WhatsApp, Facebook, Twitter, etc. Those social media engage the students to learn. Based on WhatsApp also is a tool to give information and it can be used in learning and teaching material. In addition, WhatsApp is suitable tool to facility form of learning. This platform can be selected by the students what the students' needs for their learning. The student can check the chronological history based on their need and it is free access that has been saved in students' devise. Shortly, the students can revisit the material that has discussed in their own place and time[13].

\section{Speaking}

Speaking is ability to communicate each other to send and receive the information between listener and speaker. English speaking ability is the ability to express the feeling by words to get the purpose of conversation and interaction[14]. It needs some items to fulfil the conversation such as language structure and vocabularies in the good context, using a certain pronunciation, and applying appropriate ways in the English language. In addition, speaking is one of the ways to communicate each other for expressing our ideas and thinking in a message orally. As long as, the students communicate each other, the people need to apply the language in the real life as communication[15]. In addition, speaking is complete skill than the other skills, which should be taught everywhere, and it is better when the learner learn in a group[16]. Likewise, speaking is interactive to make a meaning that involves producing, receiving, and processing information[17]. Speaking should be applied for project based to improve speaking achievements for students, for example is mini drama performance.

To improve speaking, the speaker and listener have to understand the content of conversation. Content is important part of being speaker, the content is related to the judgments of speaker's personality. When the speaker have different content stimulus type, personality, it means that the content influence the understanding of the listener. Further, the new speaker struggles for understanding the meaning especially for the context of social for those who lived in Wales to communicate English with the community[18]. The new speakers face challenges over the validity of linguistic resources [19]. Thus, the speaker interprets the content of the listeners by gesture. This perspective enabled to simulate authentic, real world deception in a controlled and relatively natural context[20]. By applying these things, the speaker chooses when to lie and when to tell the truth. That is way, understanding about the content is really important to communicate each other. Based on the definition of speaking, the researcher concludes that speaking is expressing the idea by understanding the content of whether it is speaker or listener to transfer each other. The purpose of speaking itself understands of the message.

\section{Whatsapp}

WhatsApp is a media to share information and send message for written or spoken forms. WhatsApp allows people to exchange messages, send videos, written messages, photos, voice messages or voice calls via Internet connections through Blackberry, Windows Phone, iPhones, Android and Nokia phones. In WhatsApp, people need to download in the phone but another user must have it also. After downloaded, the users can start sending messages to other users having the same application. This means that WhatsApp messages can only be received by other WhatsApp users, and its service replaces the normal SMS text messages. In addition, WhatsApp is one of tools in social media. It has been famous for the youth as advanced earlier and it is actively engaged in online communities. In the colleges, WhatsApp is the majority for the students and lecturer to have mobile phones. It is also the vigorously engaged in online communities [13].

\section{Methodology}

The research will demand on the speaking course of the students in University Muhammadiyah Luwuk Banggai. It identifies the needs of students after that the researcher will develop the instructional material by using WhatsApp Then, the objectives of this research are to find out the characteristics of WhatsApp -based instructional materials for speaking class, the model of social media-based instructional materials for speaking class, the development product of social media-based instructional materials for speaking course, and the perception of the students for social media based instructional materials for speaking class. To find out the objectives of the research, the researcher will apply based on R \& D by Gall. There are ten steps should be applied for the research and development, they are assessing need to identify goal, conduct instructional analysis, analyze learners and content, write performance objectives, develop assessment instrument, develop instructional strategy, develop and select instructional materials, design and conduct formative evaluation of instruction, revise instruction, and design and conduct summative evaluation. The researcher conducted this research at Universitas Muhammadiyah Luwuk Banggai. The students will consist of 20 students in speaking class. The trying out will be the students of English Education Department 2021/2022. 
The researcher will implement the material to develop for speaking skill especially in speaking class. Techniques of collecting data were observation, interview, and questioners.

\section{Findings and Discussion}

The aim of environment analysis is to know the situational factors that can affect teaching and learning. The environment analysis consists of three parts, such as for the learners, for the lecturer and for the situation. Those are explained as following for the learners are based on the questioners and interview, the researcher got information that the researcher should be use appropriate activities, some translation, use first language, set general of purpose goal especially for material, use high motivation, recycle activities for the students. Then, the speaking material should provide audio and video through WhatsApp and another technology to support. Not only that, the lecturer should use complete set of course for book material such as key answer and homework. The last is about the time of material, it should be limited goals to set up the time as long as it is enough in teaching speaking. Furthermore, speaking material has some activities to encourage the speaking skill for the students. For example, is to discuss in the classroom, to have good grammar, pronunciation and many vocabularies. So that it indicates that, the speaking material should be orientated in that point. In addition, WhatsApp application can improve the speaking skill of the students. Then, it is for the lecturer. The lecturer provides ready activities and group work in discussion and provides a complete set of course material, homework activities and answer key in order to guide the students and lecturer in speaking activities in the classroom. The facilitation in speaking class is supported by the technology such as television, laptop and hand phone that create a good environment for the students and lecturer to study English.

The last is the situation in speaking class used group work discussion and the students does not require for course book because the lecturer has given through WhatsApp for the e-book. Even there was e-book, the students should provide a handbook for focusing material. It is for to settle limited goals as guidance for the students and lecturer itself. The situation should have audio and video material in the kind of task delivering. In addition, the speaking material should put time into preparing the course in order the time is enough to apply in speaking course. The Student's Needs, to know the characteristic of the instructional material for speaking skill, the researcher conducted some steps; they are determining the potential process by the learners and analyzing the student's need for an instructional material by identifying the lack, wants and necessities.

The important thing of need analysis is lack, the researcher found some lacks by giving the questioner and interview to the lecturer and students. The lack of this research from the students are mostly the students are in the elementary level to speak English. It can be seen when the students are speaking English in the classroom, the students are less of vocabularies to speak, less of grammar to learn and the pronunciation and spelling needs also to improve, and the technology is for the learning and teaching process. Even the technology is good enough to apply but during the observation, the students sometimes are lack of internet. So that the lecturer should make sure before the students enter to the classroom. The students' have internet or quota to access the material that has given by the lecturer.

Wants is about the willingness of the students during the learning and teaching process. The students' wants in this research are the student's want to use English in their daily activity in order to speak English fluently; the students' hope is to use also Indonesia language in learning process because sometimes the students do not understand about the English well. The students' want is to combine it, students' wants is also to attend seminar international for applying their speaking. In addition, speak with native or non-native speaker are important to practice English, the review, conclusion and key answer are the wants' of students in order for them it is easy to study when the students are at home without the lecturers, $t \mathrm{t}$ is about technology, the students' wants to apply Edmodo and WhatsApp during the learning process because it is good enough to apply and also students are happy and interesting to share each other about speaking material.

The necessities of the students and the lecturer during investigation of this research are the students' needs to improve their speaking ability because the students are still lack of speaking ability such as grammar, vocabularies and pronunciation, the student's necessities also are more active in the classroom during discussion to get the point of learning English, the students' necessities is the capability to give the feedback whether from lecturer or students each other, the students need answer key, discussion, conclusion and reviewing in speaking material, and mother aspect is about the technology, the students need to follow revolution industry 4.0 in order to upgrade the students' skill in speaking English. The point is the students' needs it because it is for maintain and encourage the students to be better teachers or lecturers in the future.

The characteristics of need analysis is the instructional material is based on the students' need and design of curriculum in order to get the interesting and motivating of the students itself. The characteristic of need analysis are the materials covers of English for the student's activity, the material designs to understand the students in speaking English with the combination between English and Indonesia, the objectives of material are communication setting formal whether it is between student and student or lecturer and students, here are some quiz to apply of speaking materials, the topics talk about communication in order the students is more interesting to speak, the material 
is discussion to express the idea of the students, the material is surrounded of speaking for non native and native speaker, the material provide by grammar, vocabularies, spelling and pronunciation, the material provides by answer key, review the previous and next materials and also conclusion, and the material touches of technologies such as Edmodo Application and WhatsApp Application to support learning activities.

The result of need analysis of this research to know the performance gaps between the student's need and the instructional material should be. It is to identify the need and the existing problems and conducting the analysis of instrument. The point of this step is to find out the characteristics of the instructional material based on WhatsApp in speaking skill of Education English Department in the Second Semester in Universitas Muhammadiyah Luwuk Banggai by using ADDIE. It is to know the characteristic of the instructional material for speaking skill. It is supported by Nation and Macalister about need analysis. Need analysis is about to know the needs to be learn and the learners want to learn. It is commonly at the goals and contents of the instructional material. A good analysis is asking the right questions and finding answers in the most effective way. The goals of need analysis consist of language, ideas, skills, and text.

The students used questioners and interview to get a good instructional material. The respondent are the students and there are 141 questions for the students and 20 questioners

The findings also related to the used of instructional material for speaking skill should be authentic. It is based on some experts stated instructional material is important to explain during making course book for teaching and learning process.

Based on the findings, the research for instructional material based on Whatsapp for speaking classroom in private university: a need analysis as following the characteristics of instructional material based on Whatsapp for speaking classroom in private university. The materials covers of English for the student's activity, the material designs to understand the students in speaking English with the combination between English and Indonesia, The objectives of material are communication setting formal whether it is between student and student or lecturer and students, there are some quiz to apply of speaking materials, the topics talk about communication in order the students is more interesting to speak in using online, the material is discussion to express the idea of the students, the material is surrounded of speaking for non-native and native speaker, the material provide by grammar, vocabularies, spelling and pronunciation, the material provides by answer key, review the previous and next materials and also conclusion and the material touches of technologies such as WhatsApp Application to support learning activities.

\section{Conclusion}

It can be concluded that need analysis is essential things in learning and teaching material, it can be good way to measure the ability of students and the lack, want and also necessities for the students in teaching by using WhatsApp Media. The researcher gave some suggestions that related to this research, the suggestions are for the need analysis of the students, before the lecturer teaches the students. The lecturer has to find the need analysis for the students itself. It is the gap performance between the lack, wants, and necessity of the students. Then, the videos are provided by the lecturer to the students should be various because it can give more motivation for the students in learning and teaching process. Next, the lecturers should use online and offline as media in learning and teaching. It is for the significant for the students and lecturer itself. For the last is about for the next researcher, it should be more various not only for speaking part but it should be writing, listening and reading.

\section{References}

[1] S. W. Amadioha, "The Importance of Instructional Materials in Our Schools an Overview," New Era Res. J. Human, Educ. Sustain. Dev., vol. 2, no. March 2009, pp. 61-63, 2009, [Online]. Available: http://ijaahnet .com/ vol-4-no-2-december-2016-abstract-4-ijaah.

[2] R. O. Bukoye, "Utilization of Instruction Materials as Tools for Effective Academic Performance of Students: Implications for Counselling," Proceedings, vol. 2, no. 21, p. 1395, 2019, doi: 10.3390/proceedings2211395.

[3] Y. R. Su and E. H. Selamat, "Fostering Students' Self-Esteem in Speaking by Extending Speaking Activities in Social Media," vol. 7, no. 1, pp. 65-74, 2019, doi: 10.32332/pedagogy .v7i1.1544.

[4] Z. Kralova, "Nonnative EFL Teachers ' Speaking Anxiety: Post-Communist Country Context," 2019, doi: $10.1177 / 2158244019846698$.

[5] P. Robertson, "The Asian EFL Journal December 2018," vol. 20, no. 12, 2018.

[6] L. Achimugu, "Availability and Utilization of IAchimugu, L. (2017). Availability and Utilization of Instructional Materials for Teaching Chemistry in Senior Secondary Schools, 4(3), 33-43.nstructional Materials for Teaching Chemistry in Senior Secondary Schools," vol. 4, no. 3, pp. 33-43, 2017. 
[7] A. Kesh, "Importance of Education Technology in teaching and learning," no. 1, pp. 2530-2540, 2017.

[8] A. B. Olayinka, "Effects of Instructional Materials on Secondary Schools Students ' Academic Achievement in Social Studies in Ekiti State , Nigeria," vol. 6, no. 1, pp. 32-39, 2016, doi: 10.5430/wje.v6n1p32.

[9] E. P. Nimasari, "The Asian EFL Journal," Asian EFL J., vol. 20, no. 4, p. 261, 2018.

[10] A. G. Irawan, N. Padmadewi, and L. P. Artini, "Instructional materials development through 4D model "," vol. 00086, pp. 1-4, 2018.

[11] G. Appel, L. Grewal, R. Hadi, and A. T. Stephen, "The future of social media in marketing," J.Acad. Mark. Sci., vol. 48, no. 1, pp. 79-95, 2020, doi: 10.1007/s11747-019-00695-1.

[12] G. C. Joshi, M. Paul, B. K. Kalita, V. Ranga, J. S. Rawat, and P. S. Rawat, "Mapping the social landscape through social media," J. Inf. Sci., 2019, doi: 10.1177/0165551519865487.

[13] O. Abraham and A. Fanny, "Social Media in Teaching-Learning Process: Investigation of the Use of Whatsapp in Teaching and Learning in University of Port Harcourt," Eur. Sci. J. ESJ, vol. 15, no. 4, 2019, doi: 10.19044/esj.2019.v15n4p15.

[14] S. Somjai and A. Jansem, "The Use of Debate Technique to Develop Speaking Ability of Grade Ten Students at Bodindecha (Sing Singhaseni) School," J. Bord. Educ. Res., vol. 13, no. 13, pp. 27-31, 2015.

[15] D. Efrizal, "Improving Students ' Speaking through Communicative Language Teaching Method at Mts Ja-alhaq , Sentot Ali Basa Islamic Boarding School of Bengkulu , Indonesia," Int. J. Humanit. Soc. Sci., vol. 2, no. 20, pp. 127-134, 2012.

[16] A. Derakhshan, A. N. Khalili, and F. Beheshti, "Developing EFL Learner's Speaking Ability, Accuracy and Fluency," English Lang. Lit. Stud., vol. 6, no. 2, p. 177, 2016, doi: 10.5539/ells.v6n2p177.

[17] Nurwachid, D. Anggani, L. Bharati, and D. Rukmini, "Developing Discovery-Based Writing Assessments to Stimulate Students ' Critical Thinking and Creativity," vol. 8, no. 3, pp. 350-358, 2018.

[18] G. Mahrholz, P. Belin, and P. McAleer, "Judgements of a speaker's personality are correlated across differing content and stimulus type," PLoS One, vol. 13, no. 10, pp. 1-22, 2018, doi: 10.1371/journal.pone.0204991.

[19] M. Hornsby and D. Vigers, "'New' speakers in the heartlands: struggles for speaker legitimacy in Wales," J. Multiling. Multicult. Dev., vol. 39, no. 5, pp. 419-430, 2018, doi: 10.1080/01434632.2018.1429452.

[20] J. E. Loy, H. Rohde, and M. Corley, "Cues to Lying May be Deceptive: Speaker and Listener Behaviour in an Interactive Game of Deception," J. Cogn., vol. 1, no. 1, p. 42, 2018, doi: 10.5334/joc. 46. 